Article

\title{
Cooling Water: A Source of Conflict in Spain, 1970-1980
}

\author{
Diego Sesma-Martín 1,2(1) \\ 1 Economics Department, Public University of Navarre, 31006 Pamplona, Spain; diego.sesma@unavarra.es; \\ Tel.: +34-948-169340 \\ 2 Institute for Advanced Research in Business and Economics (INARBE), 31006 Pamplona, Spain
}

Received: 27 April 2020; Accepted: 4 June 2020; Published: 6 June 2020

check for updates

\begin{abstract}
Water resources are limited and uneven in space and time. Competition for the use of the resource can lead to conflicts between water users. Besides its use for irrigation and agriculture, water is an essential input in the thermoelectric power generation process. Massive Spanish nuclear program projects have conditioned water management in the country, as significant freshwater volumes need to be constantly available for the proper operation of these facilities. Water for cooling has conflicted with other water-using activities, resulting in regional imbalances. The present study shows that cooling water represented a source of conflict between irrigators and electricity companies in Spain in the 1970s and 1980s. A historical analysis of documentary sources reveals that the drawing off of fresh water for cooling by the nuclear industry was one of the many causes of frequent disputes and the rise of social movements against the installation of nuclear power plants in Spain during that period.
\end{abstract}

Keywords: cooling water; thermoelectric power generation; irrigation; water constraints; overexploitation; regional imbalances; Spain

\section{Introduction}

Freshwater resources are globally scarce. The Earth contains about 1386 million cubic kilometers of water, but only about 2.5 percent of this is fresh water [1]. In addition to glaciers, fresh water derives from precipitation, meaning its availability is uneven in space and time. Fresh water has multiple functions. However, its exploitation as a productive asset to serve economies has prevailed over other roles for decades, resulting in different water footprints-that is, the effect of the impact of human activity on water resources, as volumes allocated to one purpose are no longer available in the same location and period of time for other purposes [2,3]. Traditionally, agriculture, and, later, energy production have represented the most water-intensive activities worldwide. Extensive research has taken place into water for irrigation and food production [4-6], and studies on water for energy have abounded in recent years [7-9]. Population growth and economic development have created increasing pressures on freshwater resources, which, coupled with the particular circumstances of the resource (i.e., limited and uneven availability) have, over time, led to tensions among freshwater competitors. The competition between communities for the control of, and access to, water has even on occasions resulted in violent conflicts [10-12].

Water plays a crucial role as an energy input. Water is necessary in almost all energy processes: fuel extraction, refining and processing, transportation and storage, and electricity generation [13]. In the European Union, energy production accounts for 44 percent of total water removals [14]. Electricity generation uses the greatest volumes of water of all the energy processes [15]. Hydropower plants and thermoelectric power stations (that is, fueled by coal, fuel-oil, gas, and uranium) depend heavily on water [16]. Unlike hydroelectric power plants, which use moving water flows in rivers 
to create electricity, thermoelectric power facilities remove water for cooling directly from rivers, lakes, or seas/oceans. Cooling is the most water-intensive activity of the thermoelectric generation process [17]. The location of thermoelectric power stations is the essential question in the planning of the installation of these facilities, especially in arid and semi-arid regions. Thermoelectric power plants located in areas lacking ample water supplies are vulnerable to operational disruptions, and even closures. These facilities can also jeopardize water availability for other essential activities. As a result, water concerns have hindered power plant construction and operations in many regions worldwide [18].

Spain suffers from complicated hydrography and orography, irregular rainfall, and scarce water flows. These features make Spain Europe's most arid country [19]. Spain has a long tradition of water resource management [20]. However, this system of governance, with more than 2000 years of history, has been unable to prevent water from being a subject of debate and a source of conflict [21-24]. In terms of the energy sector, the controversies aroused by the construction of reservoirs to support the country's hydroelectric development during Franco's dictatorship stand out [25-28]. The public debate around the thermoelectric power sector has mainly focused on air pollution, radioactivity risks, and nuclear waste management, especially since the Chernobyl and Three Mile Island accidents [29-31]. Until very recently, the volumes of fresh water drawn in Spain for cooling purposes were unknown [32,33]. This dearth of knowledge meant that there was a lack of understanding of whether large scale water withdrawals would inadvertently cause problems. Nonetheless, the irrigators of the 1970s began to protest against the planned power plant projects based on theoretical figures and personal perceptions. Subsequent studies showed that they would, indeed, have had significant consequences.

The present study aims to contribute to the debate from an economic perspective: the discipline most relevant to examining the distribution of scarce resources among competing needs. Thermoelectric power plants require significant amounts of water to continuously flow through their systems to guarantee efficient operation. As a result, most of the figures used in the present study refer to water withdrawals, as my interest as an economist is to evaluate the total volumes of fresh water needed for feasible thermal power generation.

This study seeks to fill a gap in the literature by examining the role of cooling water as a source of conflict in Spain. Through a historical analysis of primary sources and press materials, this study aims to provide evidence of the environmental opposition and social movements that arose to argue against the installation of nuclear power plants in Spain in the 1970s and 1980s, and show that the removal of water for cooling by the energy industry was a critical factor in the arguments propounded by the protesters. Was water drawn off for cooling a cause of disputes in Spain? Did cooling water volumes compromise the use of the resource for other priority activities in Spain? Did competition for freshwater resources lead to tensions among the different water users? These are the main questions to be addressed.

The remainder of the paper is organized as follows: Section 2 assesses the role of water in thermoelectric power generation and discusses the Spanish thermoelectric sector's dependence on water over time. Section 3 identifies the features that shaped the conflicts and provides some examples. The discussion and future research avenues are set out in Section 4. Section 5 summarizes the main conclusions.

\section{Water: A Key Resource for Thermoelectric Power Production}

Water is a critical energy resource. A vast amount of literature exists on the water-energy nexus, covering different dimensions and geographical areas [34-37]. Electricity generation requires large amounts of water to move turbines and cool thermoelectric power generators. The thermoelectric sector is highly reliant on water resources [38]. Conventional thermal (fueled by coal, fuel-oil, or gas) and nuclear power stations heat water into steam, which then turns turbines connected to generators, producing electricity. The steam is then condensed back into water to continue the process. This condensation requires cooling water. Power plant cooling typically creates the largest water requirements in the whole thermoelectric power generation process [39]. Thermoelectric power plants use water by means of withdrawals and consumption. Withdrawal is the process of diverting water 
from a water body. Consumption refers to the volume of water lost from the original source, mainly through evaporation, after it passes through the cooling system [40]. The volume of water withdrawals and consumption for cooling is dependent on fuel type, power generation technologies, and cooling systems [41]. The vast majority of thermoelectric power facilities use two categories of wet cooling technologies: once-through cooled (open-loop) and re-circulating cooling systems (wet cooling towers). These systems have different quantitative impacts on water resources, based on their differential functioning. Open-loop systems remove water from a nearby source (i.e., river, lake, aquifer, or sea/ocean), circulate it through a steam condenser, and discharge the now warmer water into the original water body. Conversely, wet cooling towers withdraw water and circulate it within the system, while air is forced through the circulating water flows. The waste heat from the cooling water is eventually expelled into the atmosphere. As a result, open-loop cooling systems involve higher water withdrawals than wet cooling towers, while wet cooling towers have higher water consumption [42].

Water is a central theme in the history of Spanish electricity generation. First, hydropower plants, followed by conventional thermal plants, and then nuclear facilities made use of freshwater resources to supply the country's electricity needs from the beginning of the 20th century onwards. Hydroelectricity represented the largest electricity generation source in Spain until the 1960s. The economic development plans of the 1960s and early 1970s resulted in additional thermal power plants and the beginning of nuclear power generation [43]. Spain was a pioneer country worldwide in the adoption of nuclear energy, with the aim of reducing its energy dependence following the 1973 oil crisis. By 1973, Spain was already ranked third internationally in terms of producing the largest share of nuclear electricity over total electricity. In the early 1970s, Spanish nuclear planning called for 23,000 MWe of new nuclear capacity to be installed by 1985-that is, a capacity equivalent to all the power plants existing in Spain in 1973. However, following the declaration of a nuclear moratorium in 1985, only 7000 MWe was, in the event, connected to the grid [44]. Zorita, the first Spanish nuclear power plant, came into operation in 1969. By that time, hydropower generation contributed to 60 percent of the total electricity generated in Spain. Garoña and Vandellós I became operational in 1971 and 1972, respectively, and represented the first-generation nuclear power plant cluster. The 1973 oil energy crisis prompted the Spanish Government to include major new proposals in the 1975 National Energy Plan, which relied almost exclusively on nuclear energy. The construction of the second generation of nuclear power plants began in the 1970s, and of the third generation by the end of the decade. Figure 1 shows how thermoelectric generation (i.e., conventional thermal and nuclear power) already surpassed hydroelectric generation by the mid-1970s. In the late 1980s, nuclear energy alone was already contributing to more than 35 percent of the electricity generated in Spain.

The commissioning of new conventional thermal and nuclear power plants indirectly translates into additional water demands-mostly fresh water in the Spanish case. The evidence shows that, of the thermoelectric technologies, nuclear power plant water withdrawals and consumption tend to be larger per MWh generated [45]. Sesma-Martín and Rubio-Varas confirmed this in the Spanish case. On the one hand, they provided theoretical water factors per nuclear power plant and calculated the time series in terms of water withdrawal and consumption from 1969 to 2015. Specifically, they observed little use of water until the late 1970s, a significant increase in the 1980s due to the incorporation of nuclear power plants into the industrial scene, and a fairly stable scenario from 1990 onwards [32]. On the other, Sesma-Martín evaluated the operational freshwater use of thermal power stations (i.e., fueled by coal, natural gas, and nuclear) in the Ebro River basin, the most exploited Spanish water system in terms of the amount of water it contributes to the country's electricity generation [33]. This study provides information on the average use water factors of thermoelectric power plants by fuel type and cooling system type. The results showed that there were significant increases in water withdrawals and, consequently, water consumption in the 1980s, which was mainly due to the commissioning of the two Ascó nuclear power plant generation units, demonstrating again the great pressure that nuclear power generation puts on Spanish water resources. 


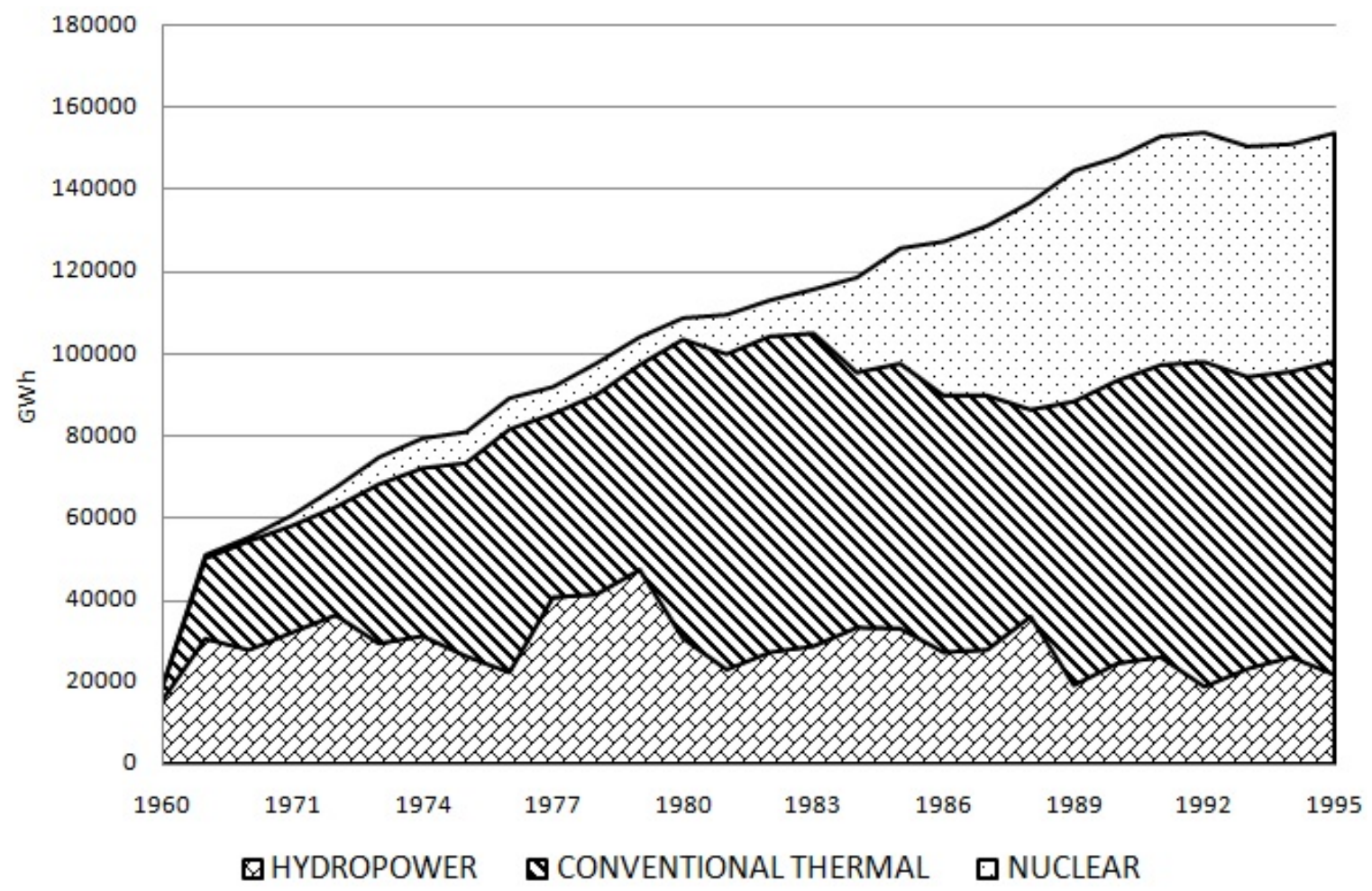

Figure 1. Evolution of Spanish electricity generation by technology, 1960-1995. Source: based on UNESA's annual reports.

\section{The Rise of Cooling Water as a Source of Conflict}

\subsection{Regional Imbalances: Plundering from 'Above,' Struggling from 'Below'}

The National Institute of Industry (INI) was established in 1941 as an institutional support for the Spanish economy; it launched substantial investments toward the industrialization of the country. The Spanish Government put itself at the service of large industries. Spatial planning strategies changed completely; agricultural land was converted for industrial use, including the location of power plants, entirely shaped to support capitalist means of production. As sociologist Artemio Baigorri stated, "territories and their uses were ordered structurally and hierarchically according to the priority objectives of GDP growth, resulting in a center-periphery argumentation whereby the peripheries became points of resource extraction, and support of the development process" [46] (p. 1). The socio-economic system established unbalanced relations, where the dominant position was held by bureaucratic-industrial cores, to the detriment of the dominated territories. These dominant clusters demanded increasing amounts of natural resources and energy from the dominated territories [47]. Territorial planning, in this case, was based on the creation of dominant and dependent areas. The future of the dependent areas was both planned without the participation of the local stakeholders, and at their expense in terms of environmental and health impacts. The installation of thermoelectric power plants clearly conditioned Spanish territorial planning, as it conflicted with other land uses and resulted in regional imbalances. This 'ecological colonialism'-the term coined by the economist José Manuel Naredo to describe the coercive relationship of domination and aggression against nature and individuals imposed by this new socio-economic system-generated strong opposition from the affected populations, which saw an uncontrolled plundering of their natural resources [48]. Disputes over natural resources began during the Franco regime and continued during the period of transition to democracy and up to the mid-1980s. In Spain, popular movements arose first against dam and reservoir construction, followed by anti-nuclear movements $[27,49,50]$. 
Opposition to nuclear power plants was especially founded on regionalist sentiment, which can be split into two streams: first, ethnic nationalism, which is a characteristic of regions such as Galicia and the Basque Country [51]; second, ecological and economic regionalism, which is typical of developing regions, such as Aragon and Extremadura [52,53]. Protests associated with regionalism aimed to tear specific competencies and decisions away from the central power and give them to the regions, understood as geographical and cultural frameworks. The State of Autonomies, which emerged from the Spanish Constitution of 1978, settled this issue by giving the regions self-government.

Historically, water has represented one of the most overexploited natural resources. As the protagonists claim, in Spain, water legislation was the legal mechanism used to underpin this unlimited use. The Water Law of 1879 dictated that all surface water and streams in Spain belonged to the state, which could distribute them according to its own criteria and rationality. This law appeared in a historical context in which the bourgeois class was consolidated in power. This legislative framework gave the state, representing bourgeois interests, very broad competence in water matters by conferring on it, among many other powers, the responsibility for authorizing industrial developments and water extraction for irrigation purposes, and of monitoring and controlling usage through water concessions [54]. Since the mid-20th century, industry has been prioritized over other types of water use at various times. The electricity companies were the main beneficiaries of this political and legal context. A clear example is the grant made in 1956 to the Ribagorzana National Hydroelectric Company, which represented about $75 \%$ of the INI, of the exclusive exploitation of all Ebro Valley waters between the municipalities of Escatrón and Flix, covering more than $200 \mathrm{kms}$ of the river [28,55]. The Spanish state later confirmed the supremacy of the energy sector, granting water concessions for cooling thermal and nuclear power plants.

These dominance patterns can be observed in the changing water management paradigms in Spain. First, a paradigm based on the domination of Spanish rivers emerged in the 19th and 20th centuries. Subsequently, a new water paradigm based on sustainability appeared in the late 20th century, consolidating itself at the beginning of the 21st century. The former, known as Regenerationism, was based on the dominant actions undertaken by the Spanish Government through supply strategies-that is, the construction of large hydraulic works, whose ultimate goals, depending on the time period, were split between irrigation and industry $[56,57]$. The latter, the New Water Culture, gave greater importance to citizen participation and advocated a water management model based on the control of water demand and scarcity adaptation [58]. The first paradigm was based on the domination of the rivers through massive state intervention. Water was seen by the state as a simple productive resource through which to promote economic and social development. Water supply strategies based on the productive approach were justified by the principle of general interest. The water demands of industry were simply seen by the state as legitimate water requirements. The state had to provide the necessary means to make water flows available, regardless of the economic costs and environmental impacts. The cultural, emotional, and identity values of water were ignored under this paradigm, and the concept of limited resource availability was also overlooked [23]. The New Water Culture originated from the unsustainability crisis caused by the first water management model. The new paradigm understands that rivers, lakes, and wetlands are living ecosystems and environmental, leisure, and cultural assets, as well as having productive benefits. In short, Spain experienced a transition from economism to sustainability from the late 1970s onwards, from which point the change in dominance relationships became clearly evident $[21,59,60]$. Table 1 provides a summary of the most representative elements of the political discourse and water management patterns in Spain. 
Table 1. Highlights of political discourse and water paradigms in Spain.

\begin{tabular}{|c|c|c|c|c|}
\hline & Political Centralization & $\begin{array}{l}\text { Decentralized } \\
\text { State }\end{array}$ & $\begin{array}{l}\text { Traditional Water } \\
\text { Paradigm }\end{array}$ & New Water Culture \\
\hline Timeframe & Late 1950 s to Mid-1970s & Mid-1970s onwards & Pre-1970s & Post-1970s \\
\hline $\begin{array}{l}\text { Territorial/Water } \\
\text { Planning }\end{array}$ & $\begin{array}{l}\text { Centralized and Structuralist. Close } \\
\text { connection } \\
\text { State-Administration-Industrialization }\end{array}$ & $\begin{array}{l}\text { Decentralized and } \\
\text { network concept }\end{array}$ & $\begin{array}{l}\text { Construction of } \\
\text { large hydraulic } \\
\text { works. Massive } \\
\text { state intervention }\end{array}$ & $\begin{array}{l}\text { Strategies for managing } \\
\text { water demand and } \\
\text { scarcity adaptation. } \\
\text { Citizen participation }\end{array}$ \\
\hline Objective & GDP growth & $\begin{array}{l}\text { Protection of the } \\
\text { environment }\end{array}$ & $\begin{array}{l}\text { Irrigation and } \\
\text { hydropower }\end{array}$ & Sustainability \\
\hline Discourse & $\begin{array}{l}\text { Center v.s. periphery } \\
\text { Bureaucratic-industrial clusters vs. } \\
\text { dominated territories }\end{array}$ & $\begin{array}{l}\text { Autonomy to } \\
\text { manage natural } \\
\text { resources }\end{array}$ & $\begin{array}{l}\text { Water as a } \\
\text { productive } \\
\text { resource }\end{array}$ & $\begin{array}{l}\text { Cultural, emotional and } \\
\text { identity values of water }\end{array}$ \\
\hline Argument & Predatory behavior & $\begin{array}{l}\text { Regionalist } \\
\text { sentiment }\end{array}$ & Water for everyone & Water forever \\
\hline
\end{tabular}

Source: own design.

\subsection{The Cooling Water Argument Within Protests}

How water is planned and managed depends on the interests of some and has implications and, indeed, risks, for others. For example, every future hydraulic work development project involves a conflict between its promoters (i.e., the administration or electricity company beneficiaries) and affected populations. On the one hand, constructing a large reservoir involves the removal of a spatial extension by flooding by water and often the expropriation of inhabited zones: for example, villages. On the other, for the state, the issue is simply contractual as, according to the aforementioned principle of general interest, it is an object that can be bought and sold. These disparities result in tensions and conflicts among stakeholders. In this context, the codes of perception and justification of the project are substantially different for both parties [61]. Promoters try to justify the project on legal-political, economic, and technical grounds. However, affected communities rely on different justifications, which are, in many cases, environmental, cultural, and identity based [22,25]. A similar confrontation pattern prevailed when numerous nuclear power plants (and some conventional thermal power stations) were projected in Spain in the 1970s.

Environmental conflicts have been defined as disagreements and disputes over access to, and the control and use of, natural resources [62]. These conflicts emerge because different users compete for limited resources and want to manage them in different ways. Tensions can also arise when stakeholders' interests are incompatible, or the priorities of some population groups are overlooked. The conflict that we are addressing in the present study - that of competition for water resources-clearly falls within these environmental disputes. Corral-Broto identified four types of environmental conflicts between 1939 and 1979 in Spain [61]: first, conflicts in rural areas over water and air pollution as a result of industrialization, which forced the electrochemical, electrometallurgical, and cellulose industries to locate to places with ample water and energy availability; second, conflicts in urban areas due to population growth and industrial pollution; third, conflicts due to the exploitation of mountain areas for mass tourism from around 1980; finally, conflicts resulting from the installation of hydropower, conventional thermal, and nuclear power plants.

In the early 1970s, the Spanish Government pre-authorized the development of 20 nuclear reactors as part of a plan to construct almost 40 in total, although only 10, in the event, became operational, due to the 1985 nuclear moratorium [44]. Figure 2 provides a detailed map of the Spanish nuclear program. The Spanish institutional framework facilitated such a boost in energy generation. The dictatorship was linked to a privately-owned electricity sector that actively influenced government decisions, leading to unchecked decision-making [63]. It was in this context that the anti-nuclear spirit emerged in Spain. Activism against nuclear power plant projects began to appear in the late 1960s and the 1970s, although the opposition was, at first, sporadic and rather localized due to Franco's dictatorship. Thus, "protest and mobilizations coincide completely with those of the authorizations from the Ministry of 
Industry to the promoters to start the project of the work" [64] (p. 50). The location of nuclear facilities in the regions became a critical issue for activists. In this context, the slogan "Not in my backyard" became increasingly visible, because the citizenry did not want thermoelectric installations to be built close to their communities due to the environmental dangers they posed. In short, the interests of the main electricity companies collided with the interests of local communities, whose anti-nuclear movements were gaining strength at the end of Franco's dictatorship in 1975. The defenders of the territories joined with local governments and the threatened economic sectors (mainly farmers and irrigator communities) to stop these nuclear projects. The Deiba association, founded in 1976 to defend the interests of the Bajo Aragón region, represents a clear example of the opposition. Its constitution made clear its objectives: "The evident popular opposition in the areas and regions to the plans that were in place to construct there factories with activities that carried inherent dangers for the environment and natural assets, and disruption, led those affected to establish associations to better combat the installations, until administrative and economic measures could be implemented that, if the projects came to fruition, would mitigate or compensate for the resultant dangers and damage. (...) Large companies are building, and plan to build, factories and power plants with questionable systems; there are well-founded reasons to believe that, in terms of choice of location, the means of authorization, the information provided, operational plans, and security, the people and entities affected by these projects should have a more important voice and rights of participation" [65] (p. 22). Thus, the areas where plants were to be installed would suffer from the overexploitation of their natural water and energy resources and the pollution generated by these industries.

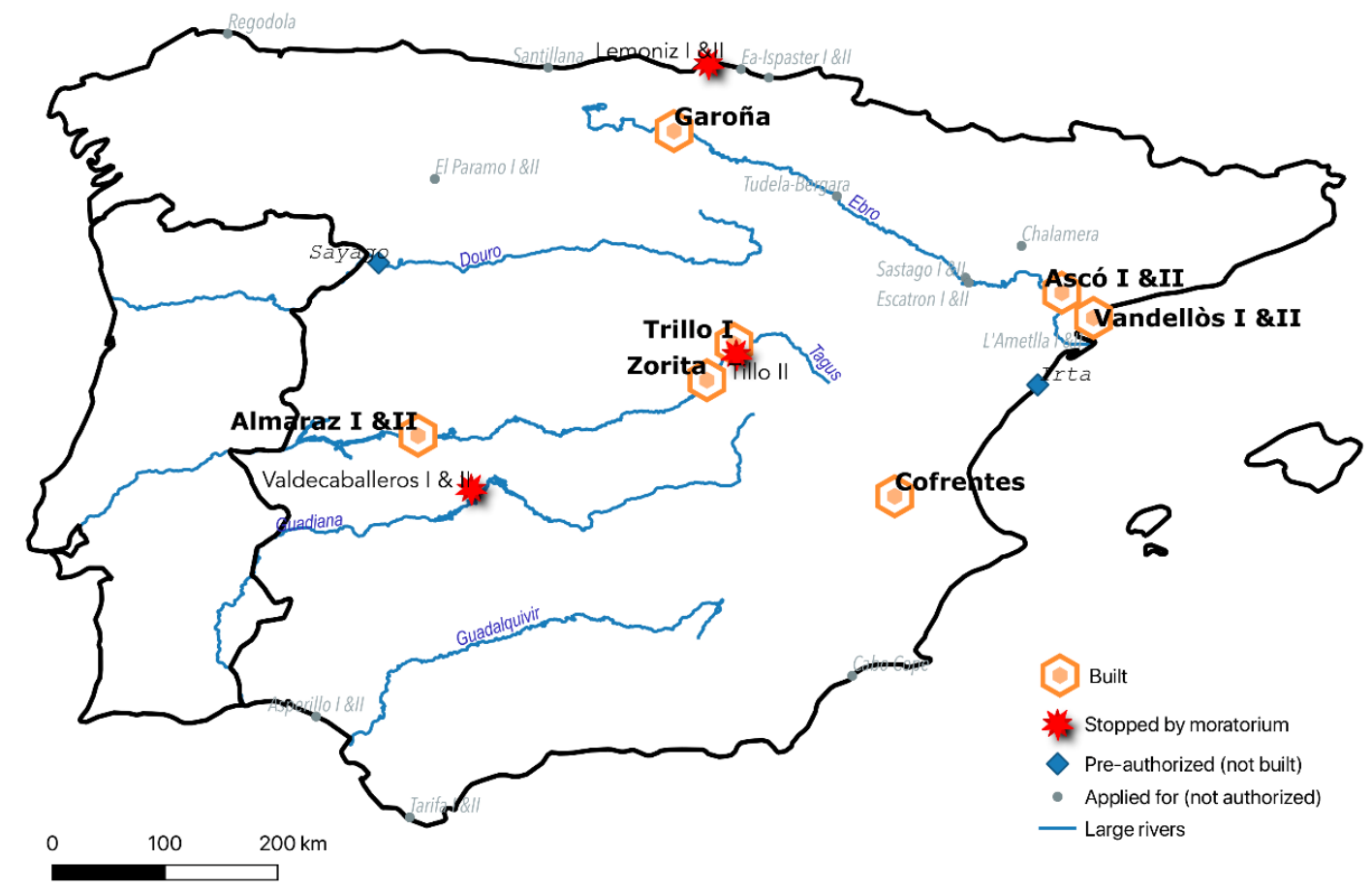

Figure 2. Nuclear power plants planned, installed, and stopped in Spain, 1960-1980. Source: originally in [44], replicated with permission.

Two Spanish territories stand out from the rest in the development of the nuclear program: the Ebro River basin and Extremadura. Although both are rather different in terms of availability of water resources, they have a key similarity in that their economies are fundamentally based on agriculture. As a result, these regions are perceived as underdeveloped and are targeted by dominant industries, such as the electricity companies. Geographically, the Ebro River basin is the largest in Spain. The basin, as a whole, contains abundant water. However, the climate is diverse due to its large size, which is reflected in the parameters, such as temperature, precipitation, and water balance. As a 
result, the basin contains arid areas, such as Bajo Aragón [66]. Extremadura, located in the Spanish Southwest, shares its water resources between two rivers: the Tagus and the Guadiana, with the former containing the greater volume of water. Drought is a common feature in Extremadura. The absence and delay of rain and inappropriate rainfall cause major regional disasters [67].

The electricity companies planned to construct many nuclear power plants in these territories. Had the plants all been built, these territories would now produce almost 17,000 MWe (around 13,000 MWe in the Ebro River basin and almost 4000 MWe in Extremadura) of the 23,000 MWe of capacity planned prior to the nuclear moratorium. In short, approximately $72 \%$ of the country's nuclear capacity was to be concentrated in these two areas. More specifically, Extremadura and Aragón (in the Ebro River basin) were to have had their water resources particularly plundered by nuclear power plants installed in their territories. Table 2 lists the planned nuclear projects. Both regions were already exporters of electrical energy to the provinces with the country's highest per capita income, such as Barcelona and Madrid. This energy flow clearly evidences the direction of the domination of the centers over the dominated territories. For example, during the period 1966-1975, Extremadura's electricity production (mainly from hydropower stations) was about $2139.5 \mathrm{GWh}$. The consumption in the region was around 441.4 GWh. Thus, Extremadura generated an export balance of 1698.2 GWh [68]. Similarly, electricity production from hydroelectric and coal-fired power stations in Aragón was 16,446 GWh, whilst local regional consumption was 10,176 GWh. Aragon's export balance during the period 1972-1974 was 6270 GWh [69-71]. Thus, there was a mismatch between the areas with the highest electricity consumption and the areas with the highest production. In turn, these electricity flows indirectly involved large virtual water exports, which represented a hidden example of the appropriation of natural resources by the large, dominant centers. The location of the nuclear power plants contributed to making the territorial imbalances more evident, which generated popular opposition and resulted in the establishment of eminently peaceful social movements.

Table 2. Nuclear power plants planned in Extremadura and the Ebro River basin (1960-1980).

\begin{tabular}{|c|c|c|c|c|c|c|c|}
\hline Region & $\begin{array}{l}\text { Nuclear Power } \\
\text { Plant }\end{array}$ & $\begin{array}{c}\text { Utilities' } \\
\text { Application }\end{array}$ & Pre-authorization & $\begin{array}{c}\text { Start of } \\
\text { Construction }\end{array}$ & $\begin{array}{l}\text { Planned } \\
\text { Capacity } \\
\text { (MWe) }\end{array}$ & $\begin{array}{l}\text { Cooling } \\
\text { System }\end{array}$ & Water Supply \\
\hline \multirow{14}{*}{ 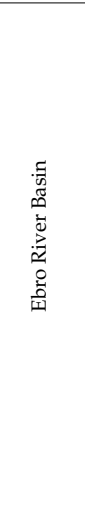 } & Garoña & 1959 & 1963 & 1966 & 460 & OL & Ebro River (Sobrón Reservoir) \\
\hline & Vadellós I & 1964 & 1967 & 1966 & 480 & OL-Gas & Mediterranean Sea \\
\hline & Ascó I & 1970 & 1972 & 1974 & 930 & CT & Ebro River \\
\hline & Ascó II & 1970 & 1972 & 1975 & 930 & $\mathrm{CT}$ & Ebro River \\
\hline & Vandellós II & 1974 & 1976 & 1976 & 930 & OL & Mediterranean Sea \\
\hline & Vandellós III & 1974 & 1976 & - & 930 & OL & Mediterranean Sea \\
\hline & Vergara (Tudela) & 1973 & - & - & 1000 & N/A & Ebro River \\
\hline & Sástago I (Aragón) & 1973 & - & - & 1160 & N/A & Ebro River \\
\hline & La Zaida (Aragón) & 1973 & - & - & 1160 & N/A & Ebro River \\
\hline & Escatrón I & 1974 & - & 1977 & $930 / 1200$ & OL & Ebro River (Mequinenza Reservoir) \\
\hline & Escatrón II & 1974 & - & 1977 & $930 / 1200$ & OL & Ebro River (Mequinenza Reservoir) \\
\hline & L'Ametlla II & 1974 & - & - & 900 & OL & Mediterranean Sea \\
\hline & L'Ametlla I & 1974 & - & - & 900 & OL & Mediterranean Sea \\
\hline & Chalamera & 1975 & - & - & 1000 & N/A & Cinca River \\
\hline \multirow{4}{*}{ 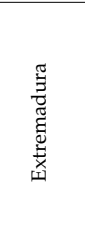 } & Almaraz I & 1970 & 1971 & 1973 & 930 & OL & Tagus River (Arrocampo Reservoir) \\
\hline & Almaraz II & 1971 & 1972 & 1974 & 930 & OL & Tagus River (Arrocampo Reservoir) \\
\hline & Valdecaballeros I & 1974 & 1975 & 1975 & 1000 & OL & $\begin{array}{l}\text { Guadalupejo River (Valdecaballeros } \\
\text { Reservoir) and Guadiana River (Garcia } \\
\text { de Sola Reservoir) }\end{array}$ \\
\hline & Valdecaballeros II & 1974 & 1975 & 1975 & 1000 & OL & $\begin{array}{l}\text { Guadalupejo River (Valdecaballeros } \\
\text { Reservoir) and Guadiana River (Garcia } \\
\text { de Sola Reservoir) }\end{array}$ \\
\hline
\end{tabular}

Source: Based on [32,44,52] and Revista Energía Nuclear (No. 91, 1974, pp. 355-357). Notes: OL: open-loop cooling;

$\mathrm{CT}$ : cooling tower; N/A: no information exists or further research is required.

\subsection{Communities Against Nuclear Power Plants: Some Identified Cases}

In addition to the primary sources, contemporary press and magazine materials are essential repositories of information on these types of conflict. The digital libraries of national newspapers, 
such as El País and $A B C$, and other regional daily press more critical of the political regime (i.e., Andalán, Triunfo, and Alfalfa, among others) are crucial documentary sources. The Appendix A contains a detailed list of the historical documents consulted. The following paragraphs describe selected cases of opposition to the installation of nuclear power plants in Extremadura and the Ebro River basin.

The main opposition to the Valdecaballeros nuclear power plant came from irrigator communities. The Badajoz Plan, approved in 1952 by the Franco government, sought to boost the Extremaduran economy, especially in agriculture, and to expand the irrigated surface area. The planned regulation of the Guadiana River through dam construction would have transformed 130,000 hectares into irrigated land from the mid-50s to the late 1980s [72]. In this context, the water cooling needs of the Valdecaballeros nuclear facility would have conflicted with the interests of the irrigators by reducing the water flows required to irrigate the extensive crops that were planned to be planted as a result of the Badajoz Plan significantly. Thus, the installation of the nuclear plant clashed directly with agronomic water use. A report attacking the Valdecaballeros nuclear power plant, produced at the behest of the Guadiana Irrigators' Communities in October 1977, stands out as an example of these tensions. The report by the Spanish sociologist and ecologist Pedro Costa Morata addressed, among many other issues, the incompatibility of water uses in the region [73]. Later, the Irrigators' Communities would be joined by the Extremaduran Anti-nuclear Association, the Extremaduran Association for the Defence of Nature and Resources (ADENEX), the Campo Arañuelo Popular Association, the Commission of Those Affected by the Valdecaballeros Nuclear Power Plant, and the Anti-nuclear Committees of Badajoz and Cáceres. Massive acts of mobilization provided evidence of this opposition. The anti-nuclear march organized by the Commission of Those Affected by the Valdecaballeros Nuclear Plant in August 1977 attracted approximately 30,000 people. Later, in 1979, the Villanueva de la Serena town hall was occupied by more than a hundred Extremaduran mayors, an impressive popular demonstration of people from all over the region [74]. Simultaneously, the press was echoing this social protest movement, which democratically represented the interests and collective will of the people of Extremadura, who had become very aware that they were an exploited and deceived community, observing how, once again, outsiders had made decisions on their behalf. This incipient regional awareness would be evidenced by the public presentation of the Declaration of Autonomy in the Management of Natural Resources in Extremadura, presented in one of the many demonstrations held in the region [47]. Furthermore, the City Council of Badajoz requested the shutdown of the plant in 1983 in a letter to the Minister of Industry and Energy. The letter stated that the province of Badajoz, one of the most drought-affected in Spain, had water sufficient only for irrigation and population supply. Meanwhile, protests against the Almaraz nuclear power plant attracted less attention, partly as a result of the success of the Valdecaballeros shutdown. The author has no knowledge of protests by irrigator communities against Almaraz.

The waters of the Ebro River, as a cheap and industrial raw material, also attracted national companies. The interests of these companies threatened the living standards of the populations of the river basin through the diversion of water for energy and other industrial uses. According to the electricity companies, the Ebro River had sufficient capacity to cool a large number of nuclear power plants. By contrast, communities that were heavily dependent on agriculture saw their water resources compromised. Between 1974 and 1979, more than a dozen demonstrations were held in urban and rural areas against nuclear power plants in defense of the environment and in support of the democratic management of regional natural resources [61,75]. The public, peaceful protests that took place in Chalamera and Escatrón are the most representative.

In the case of Chalamera, the nuclear power plant would have impacted some of the most important irrigation areas in the country (i.e., the Aragon and Catalonia Canal, the Cinca Canal, and the Monegros Canal). Thus, more than 120,000 irrigated hectares would have been affected by the nuclear power plant. Furthermore, the power station would have seriously compromised the water availability of the Cinca and Alcanadre Rivers. The water to be withdrawn by this plant was equivalent to the amount needed to irrigate 16,000 hectares. Based on an estimated water flow of 10 cubic meters per 
second in both rivers, the nuclear power plant requested 4 to 6 cubic meters per second. In short, it would have been extremely difficult to make its cooling requirements compatible with the needs for irrigation and population supply. This uncertainty about the future of agriculture in Chalamera resulted in various demonstrations-most notably, one held on 9 May, 1975 in front of the provincial government building. The creation of the Community of People Affected by the Cinca Nuclear Power Plant (COACINCA) in 1976 encouraged farmers and irrigators to continue acting, for the most part, legally, but in a combative and effective manner. The Chalamera nuclear power plant project represents a clear example of the way in which the public administrations act when trying to create industries harmful to rich agricultural areas—in this case, Aragon—-to benefit only societally powerful groups and multinationals.

Escatrón represents an exception in this context. Its population-mostly workers from a recently decommissioned coal-fired power plant-welcomed the installation of a nuclear power plant to preserve economic activity in the village. Escatrón held a referendum to gauge the opinion of local people. About $93 \%$ of the electorate voted for the installation of the projected nuclear power plant in the municipality. The referendum gave the approval for the expropriation of 180 hectares of municipal property for the installation of the new nuclear power plant. Despite this, Escatrón was unable to prevent debate and protests. A demonstration against the construction of the nuclear power station, organized by the Associations for the Defense of the Interests of Lower Aragon (DEIBA and DEIBATE) in July 1977, was attended by 4000 people, including farmers and irrigators. The water needed for cooling through an open-loop system was one of the reasons for the protest. It was argued that the total water demands of the power plant, estimated at 1040 cubic hectometers per year, would put at risk the irrigation of approximately 220,000 hectares of land.

The present study focuses on nuclear power plants, but coal-fueled thermoelectric power plants also use significant water per MWh generated, which generated additional disputes among water users. For example, a criterion for the location of the Andorran coal-fired power station (a mining region in the Ebro River basin) was its proximity to the Calanda reservoir, since the facility would be at a mid-point between the two sources of raw materials needed for its operation: coal and water [76]. Official State Bulletin (BOE No. 92, 18 April, 1977, as amended by BOE No. 287, 30 November, 1982), announced the concession of surface water from the Guadalope River of a continuous flow of 2054 cubic meters per hour for cooling the power plant. Given that the projected annual exploitation of the power plant was $5500 \mathrm{~h}$, the average annual flows could be estimated at around 12 cubic hectometers, excluding evaporation losses from the cooling towers. This figure is below the maximum volume granted by the Ministry of Hydraulic Works (that is, 18 cubic hectometers per year). However, given the deficient water resources in the Andorran district and the low flow of the Guadalope River in the dry season, the operation of the power station could cause serious disruption to 5000 hectares of the projected Guadalope Irrigation Plans. The protests made by the Central Union of Irrigators of the Guadalope River against the water grant to the power plant for cooling purposes was reported in the press at the time.

\section{Discussion}

The map of the Spanish nuclear program shows that the Trillo and Zorita nuclear power plants were to be installed in the upper reaches of the Tagus River in the Guadalajara province. This development would have caused conflict not only with the irrigator communities in the region itself, but also with the irrigators in the lower reaches of the Tagus River, who would have experienced a deterioration in both the quantity and quality of water resources. In fact, thermal pollution was an additional argument used by irrigators in their protests against the installation of thermoelectric plants in Spain. The assessment of water-related conflicts in other Spanish regions and for other types of thermoelectric power plants are potential avenues for future research.

The distinction between consumptive and non-consumptive uses of water is particularly important in this study. International studies on water use and water footprint analysis tend only to consider the 
amount of water consumed and incorporated into the production of a good or service. Water consumed in thermoelectric power production cooling processes represents a small fraction of the total water withdrawn from a water source, especially when using once-through cooling systems. The literature [77] suggests that the ratio between water withdrawal and the consumption of nuclear power plants using cooling towers is 4:2.5 cubic meters per megawatt hour generated. The same ratio for a nuclear power plant using once-through cooling is 167:1 cubic meters per megawatt hour generated. In the present study, however, the variable of interest is water withdrawal — that is, the total amount of water required to run through the system, even if only a small fraction of it evaporates. The reasoning behind the decision to focus on water withdrawals is that thermoelectric generation would be infeasible without the continuous flow of water required to cool the installations; evaporation is just a consequence of the process. Unlike other countries with greater precipitation, in Spain, a semi-arid country with cyclical water shortages, what really matters is the availability of water at a particular geographical point over a specific period of time. Thermal power plants require significant amounts of regulated and guaranteed water constantly flowing through their systems to operate their cooling processes, particularly if they use once-through cooling systems. Consequently, water withdrawals based on competing uses can limit the operation of the systems. Even if large proportions of the water withdrawn is returned to the rivers, specific flows must be available in the right place at the right time to avoid operational disruptions or even facility shutdowns [78]. During the dry months of the year, thermoelectric power plants need more water because the ambient temperature is higher. Irrigation also needs more water during the dry months. The flow of Spanish rivers becomes irregular and insufficient to satisfy the water demands of all productive activities, and the competition for the availability of this natural resource becomes more evident. This raises the issue of opportunity cost. In this context, territorial location is a crucial question in the planning of the installation of thermoelectric power plants.

Surprisingly, despite being the most arid country in Europe, a large number of the projected Spanish nuclear power plants were to be cooled by open-loop systems. Unlike cooling towers, once-through cooling systems remove significant water flows, often making the resource incompatible with other activities. The absence of a tax on water use by Spanish thermoelectric plants could explain the choice of this type of cooling system. The four planned Extremaduran nuclear units were to operate with open-loop cooling systems. This is striking in the case of Valdecaballeros (units I and II). The high irregularity of the flows of the Guadiana River throughout the year remove any guarantee that it could have met the significant, constant cooling-water demands of the units. In Official State Bulletin (BOE No. 107, 5 May, 1982) the Ministry of Hydraulic Works granted Valdecaballeros a maximum water withdrawal of 94 cubic meters per second for cooling and a maximum annual consumptive flow of 35 cubic hectometers (corresponding to 35,000,000 cubic meters). Although water volumes consumed by evaporation seem insignificant in relation to reservoir capacity in the area (estimated at 3049 cubic hectometers), the estimated water flow required by the power plant to operate at approximately $70 \%$ capacity would have amounted to 2030 cubic hectometers (i.e., 338,400 cubic meters/hour, multiplied by $6000 \mathrm{~h}$ a year). Therefore, in years with irregular and scarce rainfall, the nuclear power plant would not only have prevented the irrigation of many hectares of crops, but would also have directly affected populations and industries reliant on water from the reservoirs that regulate the Guadiana River [79]. The irrigators were right to complain. Furthermore, the construction of dams and reservoirs was a leading factor in the planning of the installation of thermoelectric power plants in Spain. Some of these reservoirs would be built to ensure a water supply for the thermal power plants and not to provide water for irrigation, as sometimes announced by the authorities. Industry took precedence over agriculture in areas with water availability problems, resulting in inadequate water management. The Arrocampo Reservoir, near the Almaraz nuclear power plant, is an outstanding example.

Finally, much of the information presented in the present study is based on the narratives produced by the protagonists. Irrigators' complaints about the cooling issue were based on perceptions rather than technical calculations, as many of the nuclear program projects were eventually suspended because of the nuclear moratorium. Nevertheless, the threats posed by these facilities to the availability of 
freshwater resources were evident, as shown by the theoretical data and projections of the environmental impact studies conducted prior to the commissioning of the plants. The lack of sufficient water to meet all competing demands is still a pressing issue in Spain. For example, the Hydrological Plan of the Ebro Hydrographic Demarcation 2015-2021 highlights that water scarcity in the area of the existing Andorra coal-fired power plant, with an annual withdrawal of 18 cubic hectometers, required agreements to be made between the various local water users to meet irrigation and energy needs [80].

\section{Conclusions}

This study demonstrates that cooling water represented a source of conflict between electricity companies and irrigators. Fulfilling all freshwater demands for irrigation and thermoelectricity was almost impossible in some regions. In Extremadura, with its low and irregular rainfall, these tensions were more evident, as having an ample water supply is an indispensable requirement when locating thermoelectric power plants. Similarly, the Ebro River basin waters would have been tightly strangled by the planned nuclear power plants, especially to the East of the region. Given the limited water resources, there were protests by irrigators and farmers over the significant amounts of water granted to cool nuclear power stations in Bajo Aragón. However, the cooling-water argument lacked this weight in other areas of the basin. Finally, this study showed how Spanish rivers were put at the disposal of the industrial sector. Some nuclear projects resulted in transformation of local agrarian economies, produced changes in land use, and in the availability of fresh water for irrigation, and, hence, led to a loss of cultural and geographical identity of communities in those territories. Nevertheless, the protests of the irrigators were, to an extent, successful, because some of the planned plants were not built, and others, like the two Valdecaballeros units, were stopped after their construction began.

Funding: This research was supported by the Spanish Government through the MINECO research projects, reference HAR2017-86086-R. The author also benefits from a research contract assigned to the History and Economics Group of the Public University of Navarre, reference 1295/2019.

Acknowledgments: I thank Mar Rubio-Varas for her helpful comments and suggestions. I also extend my appreciation for the bibliographical support of the Centro de Documentación del Agua y del Medio Ambiente de Zaragoza (CDAMAZ). Special thanks go to Javier Celma for allowing access to his personal historical archives and the time he gave to ratify some of the research data. Finally, I express my gratitude for the observations of the three anonymous reviewers and the valuable comments of Michael L. Dougherty, the Special Issue Editor.

Conflicts of Interest: The author declares no conflict of interest. The funders had no role in the design of the study; in the collection, analyses, or interpretation of data; in the writing of the manuscript, or in the decision to publish the results.

\section{Appendix A}

The following sources of information complete the extensive historical data search undertaken in the preparation of this study.

\section{Appendix A.1 National Daily Press}

El País. Available online (accessed April 21, 2020): https://elpais.com/archivo/

García, A. \& Costa Morata, P. (September 18, 1976). Faltan criterios de elección para el emplazamiento de centrales nucleares, El País.

Monroy, C. (January 2, 1977). Los regantes de Badajoz, contra la central nuclear de Valdecaballeros, El País. Monroy, C. (January 16, 1977). Piden la paralización de las obras de la central de Valdecaballeros, El País.

Costa, J. L. (February 23, 1977). Sí masivo de los vecinos de Escatrón a una central nuclear. El País.

Costa, J. L. (July 24, 1977). Manifestación contra la central nuclear de Escatrón. El País.

Costa, J. L. (March 1, 1978). Inquietud entre agricultores de Teruel por la central térmica de Andorra. El País. Costa Morata, P. (May 19, 1978). La práctica antijurídica nuclear y el PEN 78, El País.

Galán, L. (March 16, 1979). Escatrón: una elección nuclear. El País.

Leal, J. (May 1, 1979). Tres mil personas, contra la construcción de la central nuclear de Valdecaballeros, El País. 
Goñi, F. (May 29, 1979). Alcaldes navarros solicitan la paralización de la central nuclear de Soto de Vergara, El País.

Leal, J. (March 10, 1979). Jornadas de debate nuclear en Plasencia. Organizadas por la Consejería de Industria y Energía, El País.

N/A. (August 14, 1979). Reacciones en Badajoz contra la central de Valdecaballeros, El País.

N/A. (August 26, 1979). Autorizada la construcción de las centrales nucleares de Trillo y Valdecaballeros, El País.

Leal, J. (August 29, 1979). Encierro de 71 alcaldes extremeños en protesta contra la central de Valdecaballeros, El País.

Leal, J. (September 2, 1979). Diez recursos de regantes, pendientes de resolución, El País.

García, A. (September 19, 1979). Valdecaballeros, El País.

Leal, J. (September 23, 1979). Manifestaciones antinucleares en Badajoz, El País.

N/A. (May 25, 1982). Regantes del Plan Badajoz, enfrentados con la central de Valdecaballeros, El País.

Jeremías Cremente Simón (October 2,1983). Regantes del plan Badajoz piden ayuda para mantener el pleito contra Valdecaballeros, El País.

ABC. Available online (accessed April 21, 2020): https://www.abc.es/archivo/

Foncillas, J. A. (May 10, 1975). Los habitantes del Bajo Cinca, contra la proyectada central nuclear de Chalamera, ABC.

N/A. (July 26, 1977). Cuatro mil manifestantes en la concentración antinuclear del Bajo Aragón, ABC.

El Salto Digital. Available online (accessed 28 March 2020): https://www.elsaltodiario.com/

Pascual Salguero, P. J. (August 29, 2019). El día que el pueblo extremeño puso en jaque al Gobierno: 40 Aniversario de la manifestación contra la Central Nuclear de Valdecaballeros, El Salto.

Mogollón, R. \& Santos Pascua, O. A. (April 16, 2018). La lucha extremeña por cerrar Almaraz y todas las demás, El salto.

Appendix A.2 Regional Daily Press

El Heraldo de Aragón. Available online (accessed April 21, 2020): https://www.heraldo.es/ Zapater, P. (June 8, 1977). El pueblo que votó 'sí a la instalación de una central nuclear en Aragón, Heraldo. Hoy Extremadura. Available online (accessed April 21, 2020): https://www.hoy.es/

González-Conejero, A. (August 19, 1979). Valdecaballeros, la primera central que será autorizada, Hoy.

Appendix A.3 Regional Press Critical of the Dictatorship (Legal)

Andalán. Available online (accessed 28 March 2020):

http://bibliotecavirtual.aragon.es/bva/i18n/consulta/registro.cmd?id=1537

Gaviria, M. Un informe de Mario Gaviria: centrales nucleares. (December 1, 1973). Andalán, No. 30, pp. 7-10.

Gaviria, M. No a la central nuclear de Sástago. (February 1, 1974). Andalán, No. 34, p. 5.

Fernández, E. \& Granell, L. Aragón contra Aragón. (February 15, 1974). Andalán, No. 35, pp. 8-9.

Gaviria, M. Los nuevo árabes: los andorranos y sus lignitos. (March 15, 1974). Andalán, No. 37, p. 9

Gastón, E. Por un Aragón bien atómico. (June 1, 1974). Andalán, No. 42, p. 2.

Ganell, L. Por un Ebro más atómico. (August 1, 1974). Andalán, No. 46, p. 7.

Cifuentes, R. El Ebro, una cloaca. (September 1, 1974). Andalán, No. 48, pp. 8-9.

Sancho Coscolluela, C. ¿Energía nuclear o energía nacional?, (September 1, 1974). Andalán, No. 48, p. 8. Bercero Borderías, J.A., Desastre ecológico inútil. (November 15, 1974), Andalán, No. 53, p. 8.

P. Costa. Centrales Nucleares. (March 15 - April 1, 1975), Andalán, No. 60-61. p. 7.

N/A. ¿Chalamera nuclear?. (May 1, 1975), Andalán, No. 64, p. 5.

Normante. No a la central nuclear. (May 15, 1975), Andalán, No. 65, p. 5.

Ibarz, J. Frente común contra la central. (June 1, 1975), Andalán, No. 66, pp.6, 9.

Abaz, J. A. Nadie quiere la central. (June 15, 1976), Andalán, No. 91, p. 2.

Equipo Al-Tawil. Bajo Cinca: futuro comprometido. (June 15, 1976), Andalán, No. 91, p. 8. 
Ibarz, J. Coacinca. La lucha popular contra el gran capital. (June 15, 1976), Andalán, No. 91, p. 9.

Ibarz, J. En Chalamera, con Chalamera. ¡No queremos central! (June 15, 1976), Andalán, No. 91, p. 10. Gaviria, M. La lucha contra las nucleares. (June 15, 1976), Andalán, No. 91, pp. 11-12.

Delgado, A. Los Problemas del Bajo Aragón. Solución no nuclear. (June 15, 1976), Andalán, No. 91, p. 13.

Equipo Tres. La tierra baja tiene la palabra. (October 1, 1976), Andalán, No. 98, pp. 8-9.

Fandos, J. L. Escatrón: ya tenemos nuclear. (July 22, 1977). Andalán, No. 123, p. 9.

Ballester, J. Escatrón: guerra fría. (August 11, 1978), Andalán, No. 178, p. 5.

Larrañeta, P. La violencia estalló en Escatrón. (August 25, 1978), Andalán, No. 180, pp. 8-9.

Ballester, J. La ecología contra el expolio. (January 12, 1979), Andalán, No. 200, p. 29.

Appendix A.4 National Daily Press and Criticism of the Dictatorship (Legal)

Triunfo. Available online (accessed 28 March 2020): http://www.triunfodigital.com/expedientes.php Carrasco-Muñoz de Vera, C. El Ebro ¿Cuenca nuclear? (August 31, 1974), Triunfo, No. 622, pp. 25-27. Gaviria, M. Cuenca del Ebro: centrales nucleares y travase. (December 14, 1974), Triunfo, No. 637, pp. $46-48$.

Marquez Reviriego, V. Nuclearizar España. (October 16, 1976), Triunfo, No. 716, p. 63.

Roglan, J. \& Gonell, J. Centrales nucleares catalanas: una larga historia de irregularidades legales. (November 27, 1976), Triunfo, No. 722, pp. 46-47.

Costa Morata, P. Las centrales nucleares en 'ayuda' de Extremadura. (March 5, 1977), Triunfo, No. 736, p. 41.

Costa Morata, P. Nuevas campañas antinucleares. (April 30, 1977), Triunfo, No. 744, pp. 31-32.

Maestre Alfonso, J. ¡Nucleares, no! (August 26, 1978), Triunfo, No. 813, pp. $46-47$.

Baigorri, A. J. La central de la discordia. (September 16, 1978), Triunfo, No. 816, pp. 30-32.

Costa Morata, P. La batalla nuclear de Extremadura. (September 8, 1979), Triunfo, No. 867, pp. 16-18.

Baigorri, A. J. Un boletín de combate: los textos de Extremadura humillada. (September 8, 1979), Triunfo, No. 867, pp. 16-18.

Diez del Corral, F. ¿Nuclear? No gracias. (January 26, 1980). Triunfo, No. 887, pp. 49-50.

Appendix A.5 National Counter-Cultural and Ecological Press

Alfalfa. Available online (accessed April 21, 2020): http://revistaalfalfa.blogspot.com/

Equipo Tres. El Bajo Aragón Expoliado. (August, 1977), Alfalfa, No. 0, pp. 20-25.

Equipo base de Estudios Extremeños. La decadencia ecológico-agrícola del colono del Plan Badajoz. (December, 1977), Alfalfa, No. 2, pp. 5-6.

N/A. Requiem por Tarragona. (January, 1978), Alfalfa, No. 3, pp. 4-5.

N/A. El problema del Agua. (March, 1978), Alfalfa, No. 5, p. 3.

Coordinadora de Ecologistas de Navarra. La autonomía del agua en Navarra. (March, 1978), Alfalfa, No. 5, pp. 6-7.

Comité Antinuclear de Cataluña. Impacto sobre las aguas. (March, 1978), Alfalfa, No. 5, pp. 26-27.

Equipo de Estudios Extremeños. Lucha antinuclear en las Vegas del Guadiana. (May, 1978), Alfalfa, No. 6, p. 25.

N/A. Vivir en Plan Badajoz. (June, 1978), Alfalfa, No. 7, pp. 10-12.

N/A. La dictadura de la producción. (July, August and September, 1978), Alfalfa, No. 8,9,10. pp. 14-16. Baigorri, A. Ecología política y lucha de clases. (July, August and September, 1978), Alfalfa, No. 8,9,10. pp. 26-28.

Comité Antinuclear de Cataluña. Moratoria nuclear. (July, August and September, 1978), Alfalfa, No. 8,9,10, pp. 68-69.

Gaviria, M. Del agua al átomo: ideología y decadencia del electrofranquismo. (1978), Alfalfa, No. Extra, pp. 6-11.

N/A. El ciclo nuclear. (1978), Alfalfa, No. Extra, pp. 27-31. 


\section{References}

1. Shiklomanov, I.A. Appraisal and Assessment of World Water Resources. Water Int. 2000, 25, 11-32. [CrossRef]

2. Hoekstra, A.Y.; Chapagain, A.K.; Aldaya, M.M.; Mekonnen, M.M. The Water Footprint Assessment Manual: Setting the Global Standard; Earthscan: London, UK, 2011.

3. Schyns, J.F. Sustainable and Efficient Allocation of Limited Blue and Green Water Resources; Doctoral Dissertation, University of Twente: Enschede, The Netherlands, 2018. [CrossRef]

4. Mekonnen, M.M.; Hoekstra, A.Y. The green, blue and grey water footprint of crops and derived crop products. Hydrol. Earth Syst. Sci. 2011, 15, 1577-1600. [CrossRef]

5. Gerbens-Leenes, W.; Mekonnen, M.M.; Hoekstra, A.Y. The water footprint of poultry, pork and beef: A comparative study in different countries and production systems. Water Resour. Ind. 2013, 1, 25-36. [CrossRef]

6. Ran, Y.; Van Middelaar, C.E.; Lannerstad, M.; Herrero, M.; De Boer, I.J.M. Freshwater use in livestock production-To be used for food crops or livestock feed? Agric. Syst. 2017, 155, 1-8. [CrossRef]

7. Siddiqi, A.; Anadón, L.D. The water-energy nexus in Middle East and North Africa. Energy Policy 2011, 39 , 4529-4540. [CrossRef]

8. Olsson, G. Water and Energy: Threats and Opportunities; IWA publishing: London, UK, 2015.

9. Larsen, M.A.D.; Drews, M. Water use in electricity generation for water-energy nexus analyses: The European case. Sci. Total. Environ. 2019, 651, 2044-2058. [CrossRef]

10. Soffer, A.; Rosovsky, M.; Copaken, N. Rivers of Fire: The Conflict Over Water in the Middle East; Rowman \& Littlefield Publishers: Lanham, MD, USA, 1999.

11. Wolf, A.T. Shared Waters: Conflict and Cooperation. Annu. Rev. Environ. Resour. 2007, 32, $241-269$. [CrossRef]

12. Gleick, P.H. Water conflict chronology. In The World's Water, 2008-2009: The Biennial Report on Freshwater Resources; Island Press: Washington, DC, USA, 2009; pp. 151-196.

13. Gleick, P.H. Water and energy. Ann. Rev. Energy Environ. 1994, 19, 267-299. [CrossRef]

14. Collins, R.; Kristensen, P.; Thyssen, N. Water Resources Across Europe-Confronting Water Scarcity and Drought. Doctoral Dissertation, EEA Report No 2/2009. Univerza v Mariboru, Fakulteta za kmetijstvo in biosistemskevede, European Environment Agency (EEA), Copenhagen, Denmark, 2009. [CrossRef]

15. IEA (International Energy Agency). Water Energy Nexus. In World Energy Outlook 2016; OECD/IEA: Paris, France, 2016; Available online: https://www.oecd-ilibrary.org/docserver/weo-2016-en.pdf?expires=15 83415443\&id=id\&accname $=$ ocid195679\&checksum=63B08ADE12E7103194166C168699C9A8 $($ accessed on 5 March 2020).

16. Van Vliet, M.T.H.; Wiberg, D.; LeDuc, S.; Riahi, K. Power-generation system vulnerability and adaptation to changes in climate and water resources. Nat. Clim. Chang. 2016, 6, 375-380. [CrossRef]

17. Pan, S.-Y.; Snyder, S.; Packman, A.I.; Lin, Y.J.; Chiang, P.-C. Cooling water use in thermoelectric power generation and its associated challenges for addressing water-energy nexus. Water Energy Nexus 2018, 1, 26-41. [CrossRef]

18. Sovacool, B.K. Running on empty: The electricity-water nexus and the US electric utility sector. Energy LJ 2009, 30, 11.

19. Suso, J.; Llamas, M. Influence of groundwater development on the Doñana National Park ecosystems (Spain). J. Hydrol. 1993, 141, 239-269. [CrossRef]

20. Spanish Government. Ministerio de Medio Ambiente. Secretaria de Estado de Aguas y Costas. Dirección General de Obras Hidráulicas y Calidad de Aguas. Libro Blanco del Agua. 2000. Available online: http://hispagua.cedex.es/node/66958 (accessed on 20 March 2020).

21. Estevan, A.; Naredo, J.M. Ideas y Propuestas Para Una Nueva Política del Agua en España; Fundación Nueva Cultura del Agua: Zaragoza, Spain, 2004; Volume 12.

22. Mairal, G. Los conflictos del agua en España. Nómadas 2005, 22, 126-139.

23. Casajús Murillo, L. Nuevos paradigmas en la gestión del agua en España. Crisis de gobernabilidad del agua en Aragón. Los conflictos de Yesa y Matarraña. Doctoral Dissertation, Universitat Autònoma de Barcelona, Barcelona, Spain, 2012.

24. García, V.A.; Balibrea, L.F.; Social, P. Agua: La Construcción Discursiva de un Conflict; Documentos de Trabajo de Sociología Aplicada; Universidad de Murcia: Murcia, Spain, 2013; Volume 2. 
25. Mairal, G.; Bergua, J.A.; Puyal, E. Agua, Tierra, Riesgo y Supervivencia; Prensas Universitarias de Zaragoza: Zaragoza, Spain, 1997; Volume 183.

26. Viñuales, V.; Celaya, N. La Iniciativa Social de Mediación Para Los Conflictos del Agua en Aragón; La nueva administración del agua: Un espacio para el diálogo; UIMP: Madrid, Spain, 2005.

27. Carrera López, L. Aragón. ¿ agua y futuro? El Movimiento Social Anti-Pantano en el Alto Aragón: Los Casos de Yesa, Jánovas y Biscarrués. Master's Thesis, Universidad Pública de Navarra, Pamplona, Spain, 2012.

28. Camprubí, L. 'Paco el Rana': La sistematización del Noguera Ribagorzana y los límites del totalitarismo. In Los Ingenieros de Franco: Ciencia, Catolicismo y Guerra Fría en el Estado Franquista; Crítica: Barcelona, Spain, 2017.

29. Rodríguez, J.C.; Pérez-Díaz, V. Discusión y Opinión Pública Sobre la Energía Nuclear en España; Panorama Social: Madrid, Spain, 2007; Volume 5, pp. 65-81.

30. Menéndez-Navarro, A.; Vázquez, L.S. La protección radiológica en la industria nuclear española durante el franquismo, 1939-1975. Hist. Ciênc. Saúde Manguinhos 2013, 20, 797-812. [CrossRef] [PubMed]

31. Trenc, J.E.; Medina, B.; Presas, A.; Varas, M.D.M.R.; De La Torre, J. Las dimensiones sociales de la percepción de la energía nuclear. Un análisis del caso español (1960-2015). Rev. Int. De Sociol. 2017, 75, 075. [CrossRef]

32. Sesma-Martín, D.; Varas, M.D.M.R. Freshwater for Cooling Needs: A Long-Run Approach to the Nuclear Water Footprint in Spain. Ecol. Econ. 2017, 140, 146-156. [CrossRef]

33. Sesma-Martín, D. The River's Light: Water Needs for Thermoelectric Power Generation in the Ebro River Basin, 1969-2015. Water 2019, 11, 441. [CrossRef]

34. Scott, C.; A Pierce, S.; Pasqualetti, M.J.; Jones, A.L.; Montz, B.; Hoover, J.H. Policy and institutional dimensions of the water-energy nexus. Energy Policy 2011, 39, 6622-6630. [CrossRef]

35. Fang, D.; Chen, B. Linkage analysis for the water-energy nexus of city. Appl. Energy 2017, 189, 770-779. [CrossRef]

36. Gao, J.; Zhao, P.; Zhang, H.; Mao, G.; Wang, Y. Operational Water Withdrawal and Consumption Factors for Electricity Generation Technology in China-A Literature Review. Sustainability 2018, 10, 1181. [CrossRef]

37. Miglietta, P.P.; Morrone, D.; De Leo, F. The Water Footprint Assessment of Electricity Production: An Overview of the Economic-Water-Energy Nexus in Italy. Sustainability 2018, 10, 228. [CrossRef]

38. Feeley, T.J., III; Skone, T.J.; Stiegel, G.J., Jr.; McNemar, A.; Nemeth, M.; Schimmoller, B.; Murphy, J.T.; Manfredo, L. Water: A critical resource in the thermoelectric power industry. Energy 2008, 33, 1-11. [CrossRef]

39. Sanders, K.T. Critical Review: Uncharted Waters? The Future of the Electricity-Water Nexus. Environ. Sci. Technol. 2014, 49, 51-66. [CrossRef]

40. Strzepek, K.M.; Baker, J.; Farmer, W.; Schlosser, C.A. Modeling Water Withdrawal and Consumption for Electricity Generation in the United States; MIT Joint Program on the Science and Policy of Global Change; Massachusetts Institute of Technology: Cambridge, MA, USA, 2012.

41. Stillwell, A.S.; King, C.W.; Webber, M.E.; Duncan, I.J.; Hardberger, A. The Energy-Water Nexus in Texas. Ecol. Soc. 2011, 16. [CrossRef]

42. DeNooyer, T.A.; Peschel, J.M.; Zhang, Z.; Stillwell, A.S. Integrating water resources and power generation: The energy-water nexus in Illinois. Appl. Energy 2016, 162, 363-371. [CrossRef]

43. De La Torre, J.; Varas, M.D.M.R. Nuclear Power for a Dictatorship: State and Business involvement in the Spanish Atomic Program, 1950-1985. J. Contemp. Hist. 2015, 51, 385-411. [CrossRef]

44. Varas, M.D.M.R.; De La Torre, J. Seeking the Perennial Fountain of the World's Prosperity. In The Economic History of Nuclear Energy in Spain; Palgrave Macmillan: Cham, Switzerland, 2017; pp. 1-32.

45. IEA (International Energy Agency). Water for Energy: Is Energy becoming a Thirstier Resource? IEA: Paris, France, 2012.

46. Baigorri, A. Del Estado Depredador a la Región Sostenible. In Mini-Conference on The Environmental Sate Under Pressure; RC24 (ISA): Chicago, IL, USA, 1999.

47. Naredo, J.M. Características actuales del saqueo extremeño y las limitaciones que ofrecen el aparato conceptual y estadístico vigentes para analizarlo. In Extremadura Saqueada: Recursos Naturales y Autonomía Regional; Editions Ruedo Ibérico: Barcelona, Spain, 1978; pp. 57-61.

48. Naredo, J.M. Antecedentes y características de la sociedad jerárquica que sostiene en Extremadura el expolio, con especial referencia al Plan Badajoz. In Extremadura Saqueada: Recursos Naturales y Autonomía Regional; Editions Ruedo Ibérico: Barcelona, Spain, 1978; pp. 11-25. 
49. Bergua Amores, J.Á. Conflictos i liberación de energía. Los movimientos anti pantano y la reinvención de los Pirineos. Ripacurtia 2006, 4, 116-141.

50. Vázquez, L.S.; Menéndez-Navarro, A. Nuclear Energy in the Public Sphere: Anti-Nuclear Movements vs. Industrial Lobbies in Spain (1962-1979). Minerva 2014, 53, 69-88. [CrossRef]

51. López Romo, R.; LaneroTáboas, D. Antinucleares y nacionalistas. Conflictividad socioambiental en el País Vasco y la Galicia rurales de la Transición. Hist. Contemp. 2011, 43, 749-778.

52. Gaviria, M. El Bajo Aragón Expoliado: Recursos Naturales y Autonomía Regional; Deiba: Zaragoza, Spain, 1997.

53. Gaviria, M.; Naredo, J.M.; Serna, J. Extremadura Saqueada: Recursos Naturales y Autonomía Regional; Editions Ruedo Ibérico: Barcelona, Spain, 1978.

54. Menéndez Rexach, A. El Derecho al Agua en la Legislación Española. In Proceedings of AFDUC 15; Universidad de A Coruña: A Coruña, Spain, 2011; pp. 53-84. ISBN 1138-039X.

55. Gaviria, M. El Instituto Nacional de Industria como agente del colonialismo interior. In El Bajo Aragón Expoliado: Recursos Naturales y Autonomía Regional; Deiba: Zaragoza, Spain, 1977.

56. Ortí, A. Política hidráulica y cuestión social: Orígenes, etapas y significados del regeneracionismo hidráulico de Joaquín Costa. Agric. Y Soc. 1984, 32, 11-107.

57. Bartolomé, I. ¿ Fue el sector eléctrico un gran beneficiario de «la política hidráulica» anterior a la Guerra Civil? (1911-1936). Hispania 2011, 71, 789-818. [CrossRef]

58. Moral Ituarte, L.D. Desde la política hidráulica tradicional a la nueva cultura del agua. Rev. De Andorr. 2007, 7, 45-60.

59. Mairal, G.; Bergua, J.A. From economism to culturalism: The social and cultural construction of risk in the River Esera (Spain). In Anthropological Perspectives on Local Development; Routledge: Abingdon, UK, 2003; pp. 85-105.

60. Agudo, P.A. Hacia una nueva cultura del agua. Cuad. Del Cendes 2005, 22, 139-143.

61. Corral-Broto, P. Sobre la sociedad ambiental. Un intento de decolonizar el franquismo y el desarrollismo desde Europa. Hist. Ambient. Latinoam. Caribeña Rev. De La Solcha 2013, 2, 133-159.

62. Matiru, V.; Hart, N.; Castro, P. Conflict and Natural Resource Management; FAO: Rome, Italy, 2000. Available online: http://www.fao.org/forestry/21572-0d9d4b43a56ac49880557f4ebaa3534e3.pdf (accessed on 25 March 2020).

63. Sanz Díaz, B. Centrales Nucleares en España: El Parón Nuclear; Fernando Torres Editor: Valencia, Spain, 1984.

64. De La Torre, J. Who was Who in the Making of Spanish Nuclear Programme, c.1950-1985. In The Economic History of Nuclear Energy in Spain; Palgrave Macmillan: Cham, Switzerland, 2017; pp. 33-65.

65. Gaviria, M. La acción de Deiba en la defensa de los intereses del Bajo Aragón. In El Bajo Aragón Expoliado: Recursos Naturales y Autonomía Regional; Deiba: Zaragoza, Spain, 1977; pp. 22-33.

66. Barceló, D.; Petrovic, M. (Eds.) The Ebro River Basin; Springer: Berlin/Heidelberg, Germany, 2011; Volume 13.

67. Fernández, M.P.; Schnabel, S.; García, Á.J.; Lagar, D. Inventario de recursos hídricos en espacios adehesados de Extremadura mediante técnicas SIG. In La Información Geográfica al Servicio de los Ciudadanos: De lo Global a lo Local, XIV Congreso Nacional de Tecnologías de la Información Geográfica; Universidad de Sevilla: Seville, Spain, 2010; pp. 1039-1052.

68. Mateos Dávila, J.L.; Hernández González, J.M. La energía en Extremadura. Revista de Estudios Económicos y Empresariales; Universidad de Extremadura: Extremadura, Spain, 1983.

69. Ministerio de Industria, Secretaria General Técnica de Industria. Estadística de la Industria de Energía Eléctrica (1972); Ministerio de Industria: Madrid, Spain, 1972; ISBN 84-500-6379-5.

70. Ministerio de Industria, Secretaria General Técnica de Industria. Estadística de la Industria de Energía Eléctrica (1973); Ministerio de Industria: Madrid, Spain, 1973; ISBN 84-500-6867-3.

71. Ministerio de Industria, Secretaria General Técnica de Industria. Estadística de la Industria de Energía Eléctrica (1974); Ministerio de Industria: Madrid, Spain, 1974; ISBN 84-500-1391-7.

72. Ortiz, M.I.L.; Barciela, C. Autarquía e intervención: El fracaso de la vertiente industrial del Plan Badajoz. Rev. De Hist. Ind. 1998, 14, 125-171.

73. Costa Morata, P. Informe sobre la Central nuclear de Valdecaballeros a petición de las Comunidades de Regantes de las Vegas Bajas del Plan Badajoz. In Extremadura Saqueada: Recursos Naturales y Autonomía Regional; Editions Ruedo Ibérico: Barcelona, Spain, 1978; pp. 601-620. 
74. González, J.S. 1979: Extremadura no se rinde, Valdecaballeros no es negociable. In Sociedad y Movimientos Sociales [Recurso Electrónico]; Instituto de Estudios Almerienses: Almería, Spain, 2009; pp. 935-946.

75. Corral-Broto, P. Sobreviviendo al desarrollismo. Las desigualdades ambientales y la protesta social durante el franquismo (Aragón, 1950-1979). Ager. Rev. Estud. Sobre Despoblac. Desarro. Rural 2011, 10, 111-155.

76. Fandos, J.L. La central térmica Teruel: Breve descripción técnica. In El Bajo Aragon Expoliado: Recursos Naturales y Autonomía Regional; Deiba: Zaragoza, Spain, 1977.

77. Macknick, J.; Newmark, R.; Heath, G.; Hallett, K.C. Operational water consumption and withdrawal factors for electricity generating technologies: A review of existing literature. Environ. Res. Lett. 2012, 7, 045802. [CrossRef]

78. Kressig, A.; Byers, L.; Friedrich, J.; Luo, T.; McCormick, C. Water Stress Threatens Nearly Half the World's Thermal Power Plant Capacity. 2018. Available online: https://www.wri.org/blog/2018/04/water-stress-threat ens-nearly-half-world-s-thermal-power-plant-capacity (accessed on 14 January 2020).

79. Fandos, J.L. La central nuclear de Valdecaballeros en abierta contradicción con la gestión hidráulica del Plan Badajoz. In Extremadura Saqueada: Recursos Naturales y Autonomía Regional; Editions Ruedo Ibérico: Barcelona, Spain, 1978; pp. 598-601.

80. Confederación Hidrográfica del Ebro. Plan Hidrológico del Ebro 2015-2021. Available online: http://www.chebro.es:81/Plan\%20Hidrologico\%20Ebro\%202015-2021/2\%20Revisi\%C3\%B3n\%202015-21\%2 Odel\%20Plan\%20Hidrol\%C3\%B3gico\%20del\%20Ebro/2.3\%20Memoria/2.3.1.-\%20Memoria/Memoria_PH E_2015-21_V2.6.pdf (accessed on 22 May 2020).

(C) 2020 by the author. Licensee MDPI, Basel, Switzerland. This article is an open access article distributed under the terms and conditions of the Creative Commons Attribution (CC BY) license (http://creativecommons.org/licenses/by/4.0/). 